\title{
PRIMATE STEFAN WYSZYŃSKI - AN EULOGIST OF GREGORIAN CHANT
}

The reflection on the condition of the musical culture of the Church in Poland has been attempted for many years. According to Jan Stęszewski "it is permissible to define musical culture as that part of culture which is simply music and everything that is related to that music" (230). The aspect that interests us is that part of culture which is considered to be religious music and which directly concerns the liturgy of the Catholic Church. Culture is a dynamic phenomenon, linked to the spirit of a particular epoch. Therefore, it changes its existing forms of expression depending on the prevailing trends. A significant part of it is represented by works having religious content, including compositions of musical art, influenced by the inspired texts and the personal beliefs of the composers, written for the purposes of worship (Bartkowski 183). Alongside these creations of human genius, unquestionably the most important and dominant genre of music cultivated through the centuries in the Church has been and still is Gregorian chant, which is the foundation of European music culture. Although it is a creation of the Middle Ages, it is still a living and up-to-date music, and an easily recognisable symbol of Christianity that describes our identity. Its value has never become outdated, even after the widespread introduction of folk chants into the liturgy after the Second Vatican Council.

Rev. Dr habil. Piotr Wiśniewski, Associate Professor - The John Paul II Catholic University of Lublin, Faculty of Humanities, Institute of Art Studies, Department of Research on Religious Monody and Polyphony; address for correspondence: Al. Racławickie 14, 20-950 Lublin, Poland; e-mail: piotr.wisniewski@kul.pl; ORCID: https://orcid.org/0000-0001-8225-7552.

Ks. dr hab. PIOTR WIŚNIEwSKI, prof. KUL - Katolicki Uniwersytet Lubelski Jana Pawła II, Wydział Nauk Humanistycznych, Instytut Nauk o Sztuce, Katedra Badań nad Monodią i Polifonią Religijną; adres do korespondencji: Al. Racławickie 14, 20-950 Lublin; e-mail: piotr. wisniewski@kul.pl; ORCID: https://orcid.org/0000-0001-8225-7552. 
Primate Stefan Wyszyński (1901-1981) has reminded us of the universal value of this chant on several occasions, mainly in his homilies and speeches, encouraging to perform it in liturgy. Even though he did not deal with the subject of church music in an academic manner, still he spoke about it with great respect, keeping in mind its diversity and significance for the liturgy and the musical culture of the Church. As he was the son of an organist ${ }^{1}$ the matters of church music were familiar to him, and he expressed this, for instance, as Bishop of Lublin (1946-1948), by taking care of the improvement of the musical culture of the diocese. ${ }^{2}$ So far, the Primate's teachings regarding liturgical music remain rather unnoticed. However, it is worth highlighting that he was a person well versed on the direction of the ongoing changes in the liturgical life of the Church suggested by the Second Vatican Council, which was influenced by his commitment to the activities of the liturgical movement aiming at the renewal of the liturgy (Waleńdzik 245).

In this study, the aim is to recall the most important speeches of Cardinal Wyszyński on the Gregorian chant - a musical phenomenon of the medieval era, as it is sometimes referred to, in the context of the Church's enunciations on the subject at that time.

\section{THE LITURGICAL AND MUSICAL CONTEXT}

The 19th century was a challenging time for the Church, which ended up being affected by the negative consequences of the French Revolution for Christian life. Above all, it faced the threat of atheism. Nevertheless, this period became a time of renewal founded with strict respect for Catholic tradition. It was characterised by attempts to reform the liturgy and renew church music. The Church during this time was an instrument of centralisation and unanimous adherence to Roman norms. Rigorous implementation of the rules established after the Council of Trent was ensured in the liturgy. The liturgy, celebrated in a solemn manner, made the faithful into spectators and listeners. This kind of foundation became the ground for the formation of a spiritual life that was based on the liturgy. A precursor of this was the abbot

\footnotetext{
${ }^{1}$ The Primate's father, Stanisław Wyszyński (1876-1970), was an organist in Podlasie and Mazovia. Thanks to the Cardinal Wyszyński understood really well the organist's ministry, his high social position at the time, as well as current problems, especially financial difficulties. Therefore, this issue had an important place in his episcopal ministry (Misiura 203).

${ }^{2}$ Important issues raised by Wyszyński included: the spiritual and musical formation of organists, music writing, and the salary of church musicians (Lisiecki 35-48).
} 
of Solesmes, Dom Prosper Guèranger (1805-1875) (Pawlak, "Muzyk kościelny" 412). He claimed that for liturgy to be authentic, it must possess four characteristic features: antiquity, commonness, anointing and authority (Neunheuser 195). This Benedictine monk also worked on the state of Gregorian chant at that time, by initiating scientific research on it, in order to eventually bring it back to the liturgy in a form corresponding to the oldest tradition (Pawlak, "Muzyk kościelny" 412). ${ }^{3}$ He put great emphasis on the cultivation of Gregorian chant, and thus provided the foundations for the renewal of liturgical music.

The urgent need for a renaissance of sacred music was connected with its crisis, which became obvious as early as the middle of the 18th century and lasted until the 1830s. It was expressed, among other things, by a lack of understanding of the requirements of the liturgy and a lack of a sense of 'church style.' The signs were visible to varying degrees, displaying themselves in an extreme form even in the performance of operatic repertoire or maintained in concert style (Mrowiec 15; Wiśniewski, "Ks. Eugeniusz Gruberski" 203-204). This undoubtedly had something in common with the political situation in Western Europe at the time. It was a period of absolute monarchy domination with its entire splendour. This atmosphere was also naturally passed on to the church hierarchy, which attached great significance to the liturgical ceremonies. By this means, the vision of spiritual power and secular splendour had a remarkable influence on the shape of sacred music, which was intended to emphasise both the dignity of Church dignitaries and the liturgy they were celebrating (Lelen 153). Therefore, it became necessary to undertake decisive action aimed at the restoration of liturgy and music to their proper dignity. Formed in the nineteenth century, the so-called the Cecilian movement for the renewal of church music - Allgemeiner Deutschen

\footnotetext{
${ }^{3}$ The research work of the Benedictines of Solesmes on Gregorian chant had a decisive influence on the direction of the renewal of liturgical music. The monks' great merit was the discovery of the collections of medieval choral manuscripts and finding Gregorian melodic archetypes, which consequently contributed to the publication of the so-called the Vatican edition of the chant (Drewniak 87). It is worth paying attention to the problem of authentic versions of the Gregorian chant. Editio Medicaea (antiphonary 1611 and gradual 1614/15), at the request of the Holy See, corrected liturgical chants. However, it was based on erroneous assumptions, which resulted in the release of a deformed Gregorian repertoire. Poland, however, avoided the effects of the Medici editions, thanks to the Piotrków prints, which were introduced into the liturgy before the publication of the Medici books. Importantly, the traditional Gregorian chant based on handwritten records has been preserved in the codices of Piotrków. In this way, the consequences of the Medici reform were avoided. The Piotrków prints and the chorale they contain, were exceptional in Europe (Pawlak, "Rola chorału gregoriańskiego" 124).
} 
Cäcilienverein (ACV) (Haberl 222) - was a response to its crisis and secularization. It contributed, for example, to the revival and dissemination of the Gregorian chant considered the model of all religious creativity, Palestrinian polyphony, revitalization of church songs and liturgical organ playing. Cecilianism aimed to restore the liturgy of musical forms in line with church regulations. This movement, however, did not avoid certain errors and onesidedness. In its concern for the liturgical usefulness of church music and its compliance with liturgical norms, he often paid too little attention to the artistic value of the church's musical repertoire, which often consisted of compositions of average value. Propagating the ideal of Palestrinian polyphony, ${ }^{4}$ he too little appreciated newer musical styles, which could also be successfully used in church music. Nevertheless, the actions taken were important and necessary to defend the sacredness of the liturgy and music.

Gregorian singing and classical polyphony were also supported by the popes of the 20th century. After Pius X (1903-1914) announced the Motu proprio Inter Pastoralis Officii Sollicitudines in 1903, the practice of Gregorian chant was slowly revived. This was accompanied by the publication of new choral books: Kyriale (1905), Cantus Missae (1907), Graduale (1908), Officium Defunctorum (1909), Antiphonale (1912), Officium Hebdomadae Sanctae (1923) (Kania 361). This Pope admitted that all the positive qualities of church music meet in the highest degree in the Gregorian chant, which has the highest features of holiness, beauty, perfection of form and universality:

(...) it is (...) the only song that the Church inherited from the ancient fathers, which they have envied for many centuries in their liturgical books, which they directly present to the faithful, in some parts of the liturgy only rewrite and which the latest studies do happily restored to its original integrity and purity. For these reasons, Gregorian chant has always been considered the prototype of church music (...). Thus, the traditional Gregorian chant must be largely restored in the rites of worship, and everyone can take it for granted that the church rite will lose nothing in its celebration if no other music accompanies it but this singing. In particular, efforts should be made to restore Gregorian chant to the use of the people, so that the faithful, as it used to be, may again take part more actively in church services. (Inter Pastoralis Officii Sollicitudines, no. 3)

${ }^{4}$ The compositions of Giovanni Pierluigi Palestrina (1525-1594) were a model of the correctness of polyphonic music. This composer, not submitting to the requirements of some church dignitaries, wrote his works at his own discretion, without, however, contradicting the general guidelines of the Council of Trent. By retaining a certain independence in this way, he became a role model for other artists. The model he developed was called the Palestrinian or classical polyphony (Pawlak, "Odnowa muzyki" 911). 
The great importance of the Gregorian chant was then emphasized in the published documents (two encyclicals: Musica Disciplina and Musicae Sacrae Disciplina, and the Instruction of the Sacred Congregation of Rites De Musica Sacra et Sacra Liturgia) by Pope Pius XII (1939-1958). Appreciating its aesthetic values, he made it a model of liturgical singing:

This singing thanks to the close connection of music with the words of the sacred text, not only is it fully adapted to it, but at the same time it enhances its strength and meaning and penetrates the souls of listeners with the sweetness of tones. It makes it simple and ... easy, but inspired by the highest and so sacred art that it arouses sincere admiration in everyone (...). Bearing in mind the beautiful qualities of true Gregorian chant, we wish and command that it be preserved (...) in the sacred liturgical rites, used and duly developed, so that it can also be performed with dignity and piousness. (Musicae Sacrae Disciplina, no. 21)

Having a superior place among other types of music, it should be used during all liturgical celebrations according to the established patterns found in typical Vatican editions (Graduale Romanum cum Ordinario Missae, Antiphonale Romanum pro Horis Diurnis, Officium Defunctorum, Maioris hebdomadae, Officium Nativitatis D.N. Jesu Christi) (Wiśniewski, "Muzyka w liturgii" 252).

A landmark event that opened a new stage in the renewal of the liturgy was the Second Vatican Council, which recognized music as pars neccesaria et integralis of the solemn liturgy. This type of definition of the relationship between music and liturgy is fundamental to the concept of liturgical music, according to which a solemn liturgy is impossible without music. The Constitution on the Sacred Liturgy Sacrosanctum Concilium in reference to the Gregorian chant states that "the Church recognizes the Gregorian chant as her own chant of the Roman liturgy. Therefore, in the liturgy, it should occupy the first place among other types of equal singing" (no. 116). It is not our goal here to explain the facts and the reasons for the elimination of Gregorian chant from the church's musical repertoire, but it should be remembered that in the post-conciliar liturgy it was very quickly pushed to the background, it ceased to function (Baroffino 14). Fortunately, after the end of the fascination with singing in national languages, after the mass liturgy is saturated with pseudo-music, more and more voices are being heard calling for the restoration of the Gregorian repertoire in the liturgy. Demonstrated clearly by this is a renewed interest in this genre of music, and its timeless value. This is evidenced by the emerging Gregorian scholas, both profes- 
sional and amateur, which undertake attempts to reinterpret this genre of singing based on the studies of old manuscripts and performing practice of cantors from the Mediterranean and Western Europe (Wiśniewski, "Chorał gregoriański"). This school of singing still fascinates people, as was just described, and its scholars and performers spare no effort trying to scrutinize and interpret the Gregorian melodies again, providing hope that it will once more take its rightful place in the repertoire of liturgical chants.

A broadly outlined context of liturgical music shows, that the Gregorian chant is an undisputable part of the foundations of the musical culture of the Church. The centuries-old tradition made it, from the very beginning, the prime and exemplary genre of singing of the Roman Church. Its primacy was provided primarily by its sanctity and perfection of form. Thanks to the modesty of its form and the simplicity of its sound, this genre of songs, like no other liturgical one, conjures prayer-like focus and a unique atmosphere. This music remains alive still and stands as an unsurpassable design for the newer liturgical compositions. These arguments were undoubtedly wielded by Cardinal Wyszyński, who demanded that the Gregorian chant remain in its rightful place in the hierarchy of liturgical songs, and as such, that the Polish Church remain faithful to the tradition that lasted more than a thousand years, and which is worthy of continuation.

\section{COMMEMORATIO AND CONTINUUM}

\section{OF THE CHURCH'S MUSICAL TRADITION}

Primate Wyszyński had no doubts about the necessity to practice the Gregorian chant. Although he appreciated the role of folk singing, deeply rooted in the Polish tradition, he was of the opinion that it was in no way able to match the Latin monody:

The Gregorian chant, it is the artistry of the soul, (...) the blossom of the spirit, a kind of pinnacle of spiritual and prayerful disposition. It grew out of prayer and knowledge of the spirit of the Church. Therefore, it must be cherished in its magnificent golden setting in the liturgy of the Holy Church. Without knowledge of liturgy and the liturgical year one cannot (...) achieve a satisfactory performance of the Gregorian chant. It requires a great personal and prayer culture, a theological mind, and above all (...) a reliable and thorough knowledge of the Church's liturgy. (Wyszyński, "Jesteście apostołami” 291) 
This genre of singing is "a wonderful instrument to soothe people's hearts," it has in it "the special importance and grand dignity of the peaceful Church," "the strange maturity of the ages and some great prayer." Gregorian chant teaches prayer and restores the ability to focus, concentrate and direct the pained soul to God. According to the Primate, the Gregorian chant is remarkably educational, social and calming. It brings peace to hearts and to social life. The Cardinal emphasized the enormous power of the chant, which impacts all who come in contact with it. This genre of singing is especially significant thanks to its educational and social value ("Jesteście apostołami” 291).

Cardinal Wyszyński drew attention to the close connection between the Gregorian chant and the liturgy. The selection of choral songs for the liturgy cannot be accidental. This repertoire, being precisely defined for individual periods of the liturgical year, for specific ceremonies and holidays, helps in consciously participating in the liturgy by commenting on its individual parts. It forms an integral unity with the content of the ordinarium and proprium missae. Only in this way does it fulfil its function in the liturgy:

If one wanted to interpret even a single verse of the psalm, they would see, that the same words provide different flavours depending on the liturgical context in which they are scrutinized. The same verse will sound differently in your ears during Advent, when the entirety of the Church of God awaits, and it will sing differently in your soul when you perform it during the Christmas liturgy, the Passion period or Easter and Pentecost. It will sound differently yet during the dignified, maturing post-Pentecostal masses. This is very significant. One can fully realise this maturity by combining the Gregorian chant with an understanding of the spirit of particular periods of the liturgical year. (Wyszyński, "Jesteście apostołami” 291)

The Primate was aware that the Gregorian repertoire had an innate difficulty in that different chants had to be performed each day, especially those related to the proprium. He emphasized that an important feature of this genre of singing, and the area of its functioning, is its anchoring in the liturgy: "When one approaches a deeper understanding of the Gregorian chant, and when they teach it to choirs, they have to strive to understand the spirit of the Holy Church liturgy well, and care the members of the choir are familiarised with it too" ("Jesteście apostołami" 291). Only in this context has this genre of singing achieved the meaning of its existence. Only the liturgy determines the selection of this repertoire. The close relationship with the liturgical text means that it is impossible to speak about free use of 
these chants, transferring them from one liturgical rite to another. No melody in a chorale exists detached from a specific rite and text. The art of music opens itself up to a specific mystery of the liturgy by becoming liturgy itself, it is, as was accurately stated by Cardinal J. Ratzinger - "the path on which God shows his salvation" (Ratzinger 174).

One of the proofs of how highly Wyszyński valued the Gregorian chant is his strong encouragement to Fr. Władysław Zientarski, director of the Primate's Choir in Gniezno in between 1961 and 1991 (Sobczak, "Dyrektorzy Chóru" 204), to implement changes in the present repertoire according to the recommendations of the Cecilian reform of church music and to bring back choral singing in the liturgy to a much greater extent (Sobczak, Ks. Wtadystaw Zientarski 77). Such a task was not easy for the ensemble, which for more than forty years had been performing pieces by 18th and 19th century composers (Haydn, Beethoven, Schubert, Wagner). Moreover, not all of the choristers understood that a return to chorale is a return to the origins. However, following Wyszyński's request, Gregorian chant, alongside classical polyphony, has since become a significant repertoire of Sunday and festive liturgies. Most of the masses were Gregorian Masses, and there were also attempts to include the worshipers in the singing as much as possible, e.g. De Angelis Mass. Other songs were being sung alternately with the worshipers, including Magnificat during Vespers. The choir has added Te Deum Laudamus, Regina Coeli, Tantum Ergo, Veni Creator and Salve Regina to its repertoire. Undoubtedly, the number of Gregorian compositions performed was much broader and included chants of proprium and ordinarium missae (Wiśniewski, "Chór Archikatedry" 259-260).

Cardinal Wyszyński used to embrace the choristers with care and gratitude. By doing so, he demonstrated the great significance he attached to liturgical music. He encouraged the performance of Gregorian chant and classical polyphony on numerous occasions. The Primate's approach is therefore a valuable testimony and a demonstration of his concern for the proper condition of sacred music. While he respected all the genres of music authorized for the liturgy, he mostly appreciated the Gregorian chant (Ropiak, "Teologiczne refleksje" 306). He mentioned Marian antiphons and hymns as some of the oldest compositions:

From the very beginning, from its cradle, the Church has been singing. And it makes us sing over and over again. If we reach back into the Church's distant past, we will discover that the greatest hymns we are singing today come from the first centuries of its existence. Where did the wonderful Ambrosian hymn Te Deum 
take its deep inspiration from? And Gloria, in which the most aged fragments are to be found? We are told by historians of liturgical texts that "Beneath Thy Protection," that is Sub Tuum Praesidium, the antiphon we so often sing, is the oldest of many antiphons about the Mother of God. It can still be found in old Egyptian manuscripts from the 3rd or even 2nd century; not the whole of it is preserved in its present form, but only in its most essential details. Similarly, Salve, Regina, this song of invocation to our Mediatrix and Protector, which has such a wonderful significance today, developed in the early Middle Ages. (Wyszyński, "Śpiewajcie chwałę" 297)

He emphasised that the musical treasure of the Church, namely Gregorian chant, is preserved in beautifully illuminated graduals, which he referred to as "the most wonderful books of the Church" used for liturgical singing ("Śpiewajcie chwałę" 297).

The emphasis put on the role of Gregorian chant, its inestimable significance as liturgical singing and the secondary importance of folk singing show that Wyszyński was faithful to the teaching of Pius XII. He also saw the sacred repertoire as a way of voicing his hope and trusting view of the future. He particularly appreciated its aesthetic and emotional qualities. In his teachings he also appealed for young people to develop a love of the Church's singing and to make an effort to teach them Gregorian chants, such asfor example Missa de Angelis, Te Deum Laudamus, O Salutaris Hostia, Tantum Ergo Sacramentum, Veni Creator Spiritus (Waleńdzik 264-265). He considered this a great opportunity for the active participation of young people in the liturgy.

Wyszyński was aware that religious worship needs to be externalized also through music appropriate for it. Singing is of great importance in the life of the Church and in its prayer: "There is Ecclesia Orans - the Church of those who pray. There is Ecclesia Cantans - the Church of those who sing" ("Śpiewająca Warszawo" 310). Singing is an embodiment of the joy of the spirit, a purification of the psyche, it frees a human being from the inner, selfish isolation within themselves, it awakens trust and hope ("Śpiewająca Warszawo" 310-312). By doing so, he captured the essential attributes of church singing. One may wonder why the Primate was so keen on the introduction of Gregorian chant into the liturgy, even though he did not devalue native folk singing. ${ }^{5}$ Perhaps he was influenced by the ideas of the liturgical

\footnotetext{
5 "We will start our earthly life with a song, with the full load of human feelings, when we will have to 'sing Christmas carols to the little Jesus Christ, born to us today...' And now the seriousness and dignity of Gregorian singing truly fall into Polish language, which through our soul seeks its way to our heart (...). The Church has a place for such feelings and allows them to
} 
movements, which placed the issue of the believers' active participation in the liturgy in the centre of their interests, and recognised the imminent dangers, including the tendency to protestantise the liturgy by restricting it to the readings and chanting of chorales, that is songs, diminishing its character as a mystery. It is worth mentioning that the tendency to eliminate Latin chants from the liturgy as much as possible starting with the development of polyphonic music forms. As early as the Renaissance, attempts were made to substitute this singing with polyphonic compositions, and in later epochs also with instrumental music. Consequently, the tendencies to include folk singing in the framework of church services gradually intensified (Mrowiec $13 \mathrm{ff}$.). Being more and more replaced by polyphony and church songs ${ }^{6}$ the Gregorian chant remained mainly in the Office chants. However, performed in the mass liturgy, monody was not necessarily related to the Gregorian chant. ${ }^{7}$ Despite its marginalization in the liturgy, it was the genre of music that always triumphed over other proposals in the end. The Gregorian chant and its first position among the chants has never been questioned. In this sense, the position of Cardinal appears to be clearer and easier to understand. Understanding the timeless role of the chant, Wyszyński created a clear continuum of the centuries-old tradition. After all, it was the decision of Mieszko I to import the musical culture of the Western Church along with the Christian civilization. Since then, the Gregorian chant has been cultivated for centuries in Poland ${ }^{8}$ and became a permanent element

express themselves in a folk song. The Church in Poland is not only the creator of liturgical singing, but also of religious Polish singing. It nurtured the singing of the Polish people from the earliest times, perhaps even earlier than Bogurodzica. Thanks to this wonderful religious content, it has a special talent to soothe hearts" (Wyszyński, "Śpiewajcie chwałę" 301).

${ }^{6}$ The state of the Gregorian chant during this period, with the Polish elements introduced into it, is presented in detail (Feicht, Studia nad muzyka 177-181).

${ }^{7}$ In part of the ordinarium missae were added some known melodies from other Gregorian forms, e.g. antiphon or hymns. It is worth mentioning Kyrie de Passione, which gave rise to the De Passione mass, or the Credo melodies using the hymns of Pange Lingua, Vexilla Regis, Crux Fidelis, Veni Creator and others. At a later stage, fragments of melodies or whole church songs were introduced into the chants of ordinarium missae, and finally, the mass intonations of the celebrant began to be associated with the liturgical periods: Gloria in Excelsis Deo and Credo in Unum Deum. He began these chants in Latin, but on the melodies of well-known periodical songs. It is impossible to remain silent about the so-called Mass songs, intended for individual parts of the ordinarium and proprium liturgy, and then closely related to the seasons of the liturgical year (Pawlak, Spór o pieśń 16).

${ }^{8}$ Gregorian chants were adopted in Poland with the establishment of cathedrals and monasteries. The first of its cultivation centers was Poznań in the 10th century. In 1000 there were also Gniezno, Wrocław and Kraków. In the following periods, successively new centers were established: Trzemeszno, Kruszwica, Międzyrzec Wielkopolski, Opatów Małopolski, Płock, Kalisz, 
of the native musical culture. Liturgical books, initially brought by missionaries from the West (the German, French, and Italian circles), and in subsequent periods copied in successively organized local scriptures, contained a record of the Gregorian repertoire applicable in the Church. ${ }^{9}$ Thus, the repertoire is considered the property of the Roman liturgy of the whole Church, and all baptized Christians have the right to perform it.

\section{CONCLUSIONS}

There is no doubt that Cardinal Stefan Wyszyński considered knowledge of the Church's musical and liturgical tradition, that was developed with great effort over the centuries, as the best school of understanding contemporary liturgical music. The spiritual power of music has become the driving force of countless religious and liturgical compositions, which is confirmed by the fact that Gregorian chant is alive and still important point of reference in determining the liturgical value of the newly created chants. Thus, it is understandable that Wyszyński tried to instill his personal attitude towards Gregorian chant in others in order not only to protect it from being forgotten, but to make the liturgy an internal experience. The necessity of nurturing Gregorian chant was beyond doubt for him. According to the analysis of his statements on the subject, he felt obliged to spread the song that best suited the criterion of proclaiming the word of God. When propagating the music, he often explained its extraordinary power and the comfort that it brings: "Salve Regina sung over the grave, wipes tears, calms, soothes the greatest pain of parting. When we hear the cry of illos tuos misericordes oculos ad nos converte, et Jesum, benedictum fructum ventris tui, nobis post hoc exsilium, ostende - everything in us falls silent, our face dries up"; "(...) the words starts to fill us with encouragement that is full of

Sieradz and others. Undoubtedly, the very fact of establishing these centers proves the emergence and cultivation of Gregorian chant in them (Feicht, "Polskie średniowiecze" 47-48). The preserved manuscripts show that already in the 11th century Poland had relations with the most outstanding music centers in Europe of that time (Cologne, Leodium, Salzburg, Niederalteich and others). The cultivation of the Gregorian chant focused mainly on the cathedrals and Benedictine abbeys (Pawlak, "Rola chorału gregoriańskiego" 109).

${ }^{9}$ The oldest and most valuable liturgical and musical codes with a neumatic notation from the turn of the 11th/12th centuries include: Sakramentarz tyniecki (in about 1060), Pontyfikat biskupów krakowskich (before 1110), Ewangeliarz płocki (in about 1130), Ewangeliarz gnieźnieński (11th century), Missale plenarium (11th/12th centuries) (Feicht, "Dzieje polskiej muzyki religijnej" 5-50; Morawski, Historia muzyki $161 \mathrm{ff}$.). 
Sanctus, Sanctus, Sanctus!"; the song "Santus, Sanctus (...) started on earth, but he will never leave us"; "Singing the Creed your (...) grace of salvation is assured" ("Śpiewajcie Chwałę" 302-313). Thus, there is a mutual exchange between the spiritual and the sensual in the Gregorian chant, which makes the singing a path to Christian ecstasy.

Cardinal Wyszyński was aware that it was therefore necessary to educate church musicians in this area and to convince the clergy to perform choral compositions in the liturgy: "as far as possible, we need the choir of every church to sing Gregorian Mass on at least one Sunday" ("Śpiewająca Warszawo" 313). Looking at today's reality, it can be said that this calling has lost nothing of its relevance! Gregorian singing ranks first among liturgical chants, most often only on paper. In order to satisfy the Primate's postulate, it is worth considering whether it would be a good solution to introduce at least selected choral chants in all parishes, e.g. part of the ordinarium missae, in order to experience the spiritual depth of the repertoire. It would certainly contribute to the spiritual growth of believers and help to live the mystery of the Eucharist more deeply. In this way, the Gregorian chant, being the music of faith, could restore the personal experience of faith among the participants of the liturgy.

Therefore, Primate Stefan Wyszyński should be included among the great defenders and propagators of the Gregorian chant. It can be a model of conduct for all those people who try to renew church music nowadays, which depends on restoration its own singing with all the content and means of expression.

\section{BIBLIOGRAPHY}

Baroffino, Giacomo. "Gregoriańsky choral v Taliansku.” Adoramus Te, vol. 9, no. 4, 2006, pp. 14-23.

Bartkowski, Bolesław. "Muzyczna kultura religijna jako przedmiot badań muzykologicznych." Seminare, vol. 5, 1981, pp. 181-189.

Drewniak, Janusz. "Ruch cecyliański - dzieło odnowy muzyki Kościoła katolickiego XIX wieku." Liturgia Sacra, vol. 12, no. 1, 2006, pp. 77-95.

Feicht, Hieronim. "Dzieje polskiej muzyki religijnej w zarysie.” Roczniki Teologiczno-Kanoniczne, vol. 12, 1965, pp. 5-50.

Feicht, Hieronim. "Polskie średniowiecze." Studia nad muzyka polskiego średniowiecza, ed. Zofia Lissa, PWM, 1975, pp. 40-105.

Feicht, Hieronim. Studia nad muzyka polskiego renesansu i baroku. PWM, 1980. 
Haberl, Ferdinand. "Aus der geschichte desallgemeinen cäcilien verbandes." Musica Sacra, vol. 05, 1968, pp. 222-231.

Kania, Jacek. "Życie muzyczne w krakowskim klasztorze Ojców Franciszkanów (OFMConv) w latach 1908-1966." Psallite Domino. O kulturze muzycznej w tradycji franciszkańskiej, ed. Stanisław C. Napiórkowski and Stanisław Cieślak, Wydawnictwo Ojców Franciszkanów 2010, pp. 353-360.

Leleń, Andrzej. Religijna kultura muzyczna Mazowsza Płockiego 1864-1918. Książnica Płocka, 2001.

Lisiecki, Tomasz. "Odnowa kultury muzycznej Kościoła Lubelskiego w czasach posługi biskupiej Stefana Wyszyńskiego.” Roczniki Teologiczne, vol. 66, fasc. 8, 2019, pp. 35-48.

Misiura, Grzegorz. “Organista Stanisław Wyszyński (1876-1970).” Archiwa, Biblioteki i Muzea Kościelne, vol. 104, 2015, pp. 203-224.

Morawski, Jerzy. Historia muzyki polskiej. Średniowiecze, vol. 1, part I: Do roku 1320. Sutkowski Edition, 2006.

Mrowiec, Karol. Polska pieśń kościelna w opracowaniu kompozytorów XIX wieku. TN KUL, 1964.

Neunheuser, Burkhard. "Sto lat odnowy liturgicznej zapoczątkowanej przez o. Prospera Guèranger. Przeszłość i perspektywy." Ruch Biblijny i Liturgiczny, vol. 29, no. 4, 1976, pp. 195-207.

Pawlak, Ireneusz. "Muzyk kościelny na tle epoki. Przyczynek do działalności ks. Józefa Surzyńskiego (1851-1919).” Liturgia Sacra, vol. 15, no. 2, 2009, pp. 409-418.

Pawlak, Ireneusz. "Odnowa muzyki liturgicznej po Soborze Watykańskim II kontynuacją reformy trydenckiej." Scio cui credidi. Księga pamiatkowa ku czci ks. Mariana Ruseckiego, red. Ireneusz S. Ledwoń, Wydawnictwo KUL, 2007, pp. 909-914.

Pawlak, Ireneusz. "Rola chorału gregoriańskiego w kształtowaniu polskiej religijnej kultury muzycznej.” Annales Lublinenses pro Musica Sacra, vol. 3, no. 3, 2012, pp. 107-132.

Pawlak, Ireneusz. "Spór o pieśń w liturgii." Muzyka liturgiczna w Kościele katowickim 1925-2005, ed. Wiesław Hudek, Polski Związek Chórów i Orkiestr. Oddział Śląski, 2005, pp. 13-26.

Ratzinger, Joseph. Nowa pieśń dla Pana. Trans. Juliusz Zychowicz, Znak 1999.

Ropiak, Sławomir. "Teologiczne refleksje Stefana kardynała Wyszyńskiego Prymasa Polski dotyczące muzyki religijnej.” Studia Warmińskie, vol. 40, 2003, pp. 301-311.

Sobczak, Dariusz. "Dyrektorzy Chóru Prymasowskiego w latach 1959-2008." Choro Basilicae Metropolitanae Gnesnensis in memoriam (1914-2014). Księga pamiatkowa dedykowana Chórowi Bazyliki Metropolitalnej w Gnieźnie (1914-2014), ed. Piotr Wiśniewski and Dariusz Sobczak, Polihymnia, 2014, pp. 201-230.

Sobczak, Dariusz. Ks. Władysław Zientarski (1916-1991) - badacz dziejów muzyki polskiej od XV do XIX wieku. Polihymnia, 2008.

Stęszewski, Jan. "Problem wartościowania kultur muzycznych." Muzyka w kontekście kultury. Spotkania muzyczne w Baranowie, vol. 1, ed. Leszek Polony, PWM, 1978.

Waleńdzik, Piotr. "Wpływ idei ruchu liturgicznego na sposób pojmowania liturgii przez Kardynała Stefana Wyszyńskiego.” Studia Prymasowskie UKSW, vol. 3, 2009, pp. 245-268.

Wiśniewski, Piotr. "Chorał gregoriański - relikt przeszłości czy wyzwanie teraźniejszości?” Śpiew gregoriański - wczoraj $i$ dziś, ed. Jacek Bramorski and Monika Karwaszewska, Mucica Sacra, t. 16, Wydawnictwo Akademii Muzycznej im. Stanisława Moniuszki, 2020, ss. 31-42. 
Wiśniewski, Piotr. "Chór Archikatedry Gnieźnieńskiej od momentu powstania (1914) do zakończenia Soboru Watykańskiego II (1965)." Choro Basilicae Metropolitanae Gnesnensis in memoriam (1914-2014). Księga pamiątkowa dedykowana Chórowi Bazyliki Metropolitalnej w Gnieźnie (1914-2014), ed. Piotr Wiśniewski and Dariusz Sobczak, Polihymnia, 2014, pp. 239-264.

Wiśniewski, Piotr. "Ks. Eugeniusz Gruberski (1870-1923) - reformator muzyki kościelnej w diecezji płockiej." Pro Musica Sacra, vol. 13, 2015, pp. 203-214.

Wiśniewski, Piotr. "Muzyka w liturgii w nauczaniu Piusa XII.” Roczniki Teologiczne, vol. 55, fasc. 8, 2008, pp. 247-265.

Wyszyński, Stefan. "Jesteście apostołami modlitwy śpiewanej." Uświęcenie pracy zawodowej, red. Stefan Wyszyński, Religia, 1963, pp. 284-293.

Wyszyński, Stefan. “Śpiewająca Warszawo!” Uświęcenie pracy zawodowej, ed. Stefan Wyszyński, Religia, 1963, pp. 312-316.

Wyszyński, Stefan. “Śpiewajcie chwałę Jego imienia!” Uświęcenie pracy zawodowej, ed. Stefan Wyszyński, Religia, 1963, pp. 294-303.

\section{PRIMATE STEFAN WYSZYŃSKI - AN EULOGIST OF GREGORIAN CHANT}

Su m mary

The article shows the unknown aspect of the activity of Primate Stefan Wyszyński related to sacred music, which included in particular the promotion of Gregorian chant. The author extracts from his speeches the most important statements considering the singing and emphasizes its value and topicality in the liturgy of the Catholic Church. The Primate's respect for the singing is a testimony and manifestation of pastoral care to preserve the identity of the Church's musical tradition.

Keywords: Wyszyński; Gregorian chant; liturgical music; liturgy.

\section{PRYMAS STEFAN WYSZYŃSKI \\ - PIEWCA CHORAŁU GREGORIAŃSKIEGO}

Streszczenie

Artykuł ukazuje mało dotąd znany aspekt aktywności Prymasa Stefana Wyszyńskiego związany z muzyką sakralną, a w szczególności z propagowaniem chorału gregoriańskiego. Autor wydobywa z jego przemówień najważniejsze wypowiedzi na temat tego śpiewu, podkreślające jego walory i aktualność w liturgii Kościoła katolickiego. Szacunek Prymasa dla tego śpiewu stanowi świadectwo i przejaw pasterskiej troski o zachowanie tożsamości tradycji muzycznej Kościoła.

Słowa kluczowe: Wyszyński; chorał gregoriański; muzyka liturgiczna; liturgia. 